\title{
Teaching NeuroImages: MRI abnormalities in frontal lobe seizures due to nonketotic hyperglycemia
}

Hsin-Pin Lin, MD, PhD, Reordan O. Dejesus, MD, and Maria José Bruzzone, MD

Neurology ${ }^{\circledR}$ 2020;95:e941-e942. doi:10.1212/WNL.0000000000010109

Figure 1 EEG

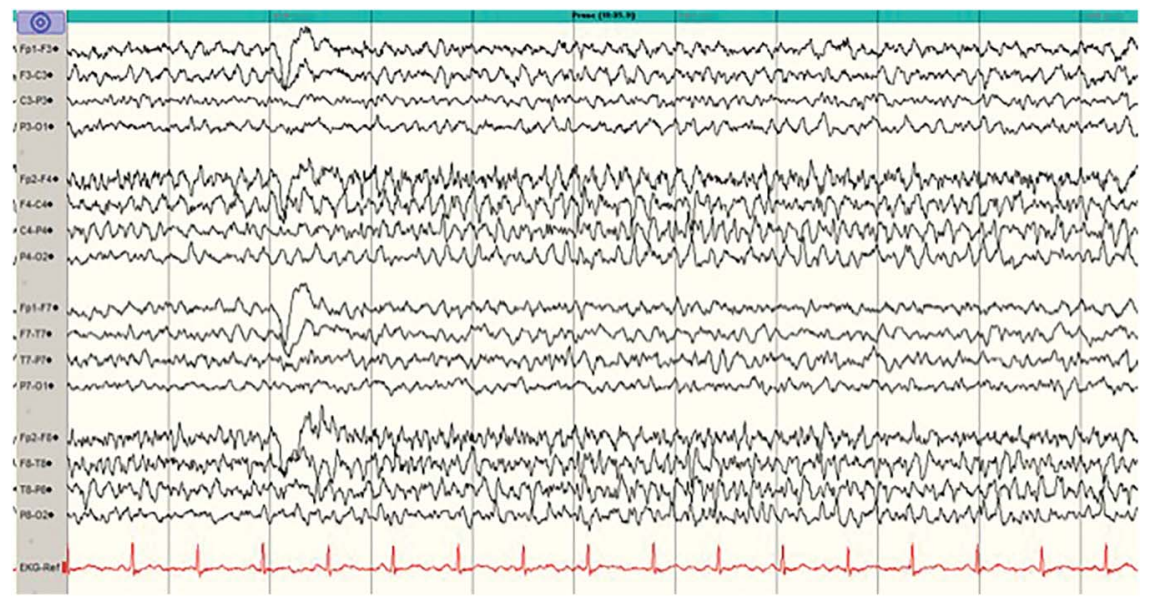

EEG shows a seizure arising from right frontotemporal area.

A 56-year-old woman presented with electroclinical focal seizures in the setting of hyperglycemia $(808 \mathrm{mg} / \mathrm{dL})$ and elevated $\mathrm{HbA1c}$ of $14.7 \%$. She had varying seizure semiology, consisting of early forced head turn to the left, speech arrest, left facial twitching, and impaired awareness. Her seizures arose from the right frontotemporal area on EEG (figure 1). MRI showed hypointensities in the right prefrontal lobe that resolved after 6 months (figure 2).

Transient T2/fluid-attenuated inversion recovery white matter hypointensities usually involving the parieto-occipital lobe have been described in patients with hyperglycemic seizures. ${ }^{1,2}$ This underreported sign may point to the diagnosis of acute symptomatic seizures in hyperglycemic patients.

\section{Study funding}

No targeted funding reported.

\section{Correspondence}

Dr. Bruzzone

Maria.BruzzoneGiraldez@

neurology.ufl.edu

\section{MORE ONLINE}

$\rightarrow$ Teaching slides links.lww.com/WNL/ B151 
Figure $2 \mathrm{MRI}$ of the brain in nonketotic hyperglycemia-related frontal lobe seizures

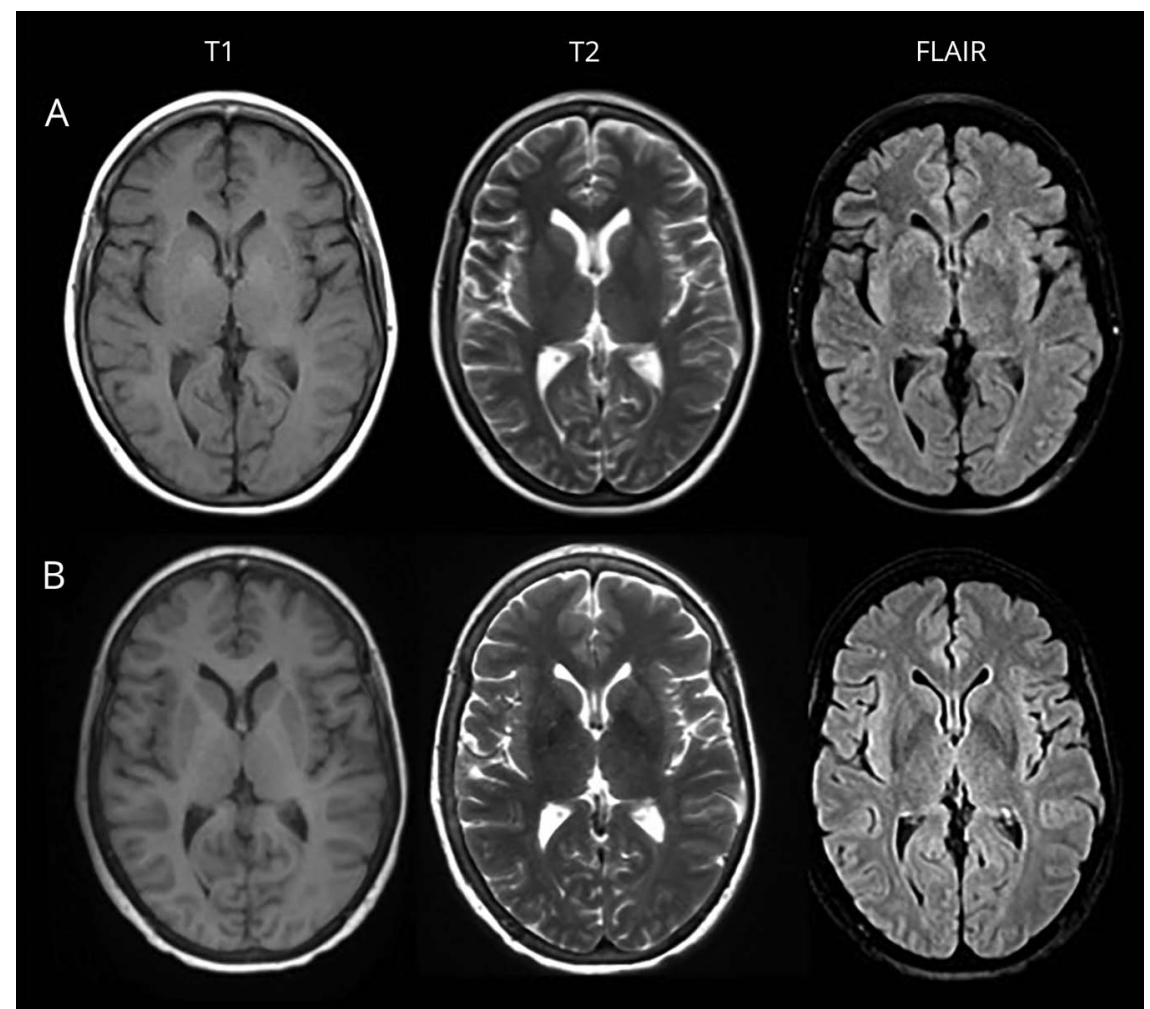

(A) Axial T1/T2/fluid-attenuated inversion recovery (FLAIR) shows white matter hypointensities in the right frontotemporal/insular regions, most prominently in the prefrontal cortex. (B) Repeat MRI shows resolution of the hypointensities 6 months later.

\section{Appendix Authors}

\begin{tabular}{lll}
\hline Name & Location & Contribution \\
\hline $\begin{array}{l}\text { Hsin-Pin Lin, } \\
\text { MD, PhD }\end{array}$ & $\begin{array}{l}\text { University of } \\
\text { Florida, } \\
\text { Gainesville }\end{array}$ & $\begin{array}{l}\text { Drafted the manuscript for } \\
\text { intellectual content }\end{array}$ \\
\hline $\begin{array}{l}\text { Reordan O. } \\
\text { Dejesus, MD }\end{array}$ & $\begin{array}{l}\text { University of } \\
\text { Florida, } \\
\text { Gainesville }\end{array}$ & Interpreted the data \\
\hline $\begin{array}{l}\text { Maria José } \\
\text { Bruzzone, } \\
\text { MD }\end{array}$ & $\begin{array}{l}\text { University of } \\
\text { Florida, } \\
\text { Gainesville }\end{array}$ & $\begin{array}{l}\text { Interpreted the data, revised the } \\
\text { manuscript for intellectual content }\end{array}$ \\
\hline
\end{tabular}

\section{Disclosure}

The authors report no disclosures relevant to the manuscript. Go to Neurology.org/ $\mathrm{N}$ for full disclosures.

\section{References}

1. Nissa Z, Siddiqi SA, Abdool SA. Occipital seizures and persistent homonymous hemianopia with T2 hypointensity on MRI in nonketotic hyperglycemia. Epilepsy Behav Case Rep 2016;6:3-5.

2. Lee EJ, Kim KK, Lee EK, Lee JE. Characteristic MRI findings in hyperglycaemiainduced seizures: diagnostic value of contrast-enhanced fluid-attenuated inversion recovery imaging. Clin Radiol 2016;71:1240-1247. 


\section{Neurology}

\section{Teaching NeuroImages: MRI abnormalities in frontal lobe seizures due to nonketotic hyperglycemia}

Hsin-Pin Lin, Reordan O. DeJesus and Maria José Bruzzone

Neurology 2020;95;e941-e942 Published Online before print July 8, 2020

DOI 10.1212/WNL.0000000000010109

\section{This information is current as of July 8, 2020}

\section{Updated Information \&} Services

References

Subspecialty Collections

\section{Permissions \& Licensing}

Reprints including high resolution figures, can be found at: http://n.neurology.org/content/95/7/e941.full

This article cites 2 articles, 0 of which you can access for free at: http://n.neurology.org/content/95/7/e941.full\#ref-list-1

This article, along with others on similar topics, appears in the following collection(s):

All Epilepsy/Seizures

http://n.neurology.org/cgi/collection/all_epilepsy_seizures

Complex partial seizures

http://n.neurology.org/cgi/collection/complex_partial_seizures

EEG

http://n.neurology.org/cgi/collection/eeg_

MRI

http://n.neurology.org/cgi/collection/mri

Partial seizures

http://n.neurology.org/cgi/collection/partial_seizures

Information about reproducing this article in parts (figures,tables) or in its entirety can be found online at:

http://www.neurology.org/about/about_the_journal\#permissions

Information about ordering reprints can be found online: http://n.neurology.org/subscribers/advertise

Neurology ${ }^{\circledR}$ is the official journal of the American Academy of Neurology. Published continuously since 1951, it is now a weekly with 48 issues per year. Copyright (C) 2020 American Academy of Neurology. All rights reserved. Print ISSN: 0028-3878. Online ISSN: 1526-632X.

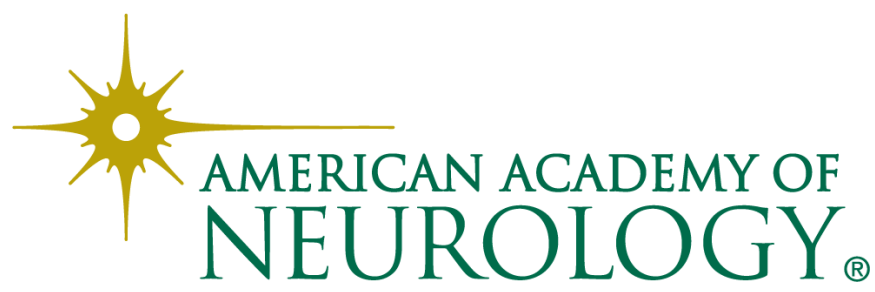

